\title{
Management Accounting as a Science: From Costs and Benefits Analysis of Productions to Strategic Planning of Uncertainty
}

\author{
Elisabetta Mafrolla \\ University of Foggia, Foggia, Italy
}

\begin{abstract}
This article discusses the role assumed by management accounting as a discipline over years. Management accounting has long lived in the shadow of financial accounting, and has been often accused of fostering productivity rather than creativity. The revolution involving the business environment in the last decades has much improved the role of creativity and innovation and the adaptability of the firm to the context often was a key to success. This article supports the innovative role of management accounting in the post-modern era, aimed at reducing the strategic dominance of the increasing uncertainty.
\end{abstract}

Keywords: management accounting, strategic planning, history of accounting, innovation, uncertainty

\section{Introduction}

Management accounting has a peculiar function among the broader accounting discipline. "Management Accounting is concerned with the provision of information to people within the organization to help them make better decisions and improve the efficiency and effectiveness of existing operations [...]” (Drury, 2003, pp. 4-5). The peculiarity of management accounting is that it is a science dealing with decision-making, whereas the remaining part of accounting is basically the science of reporting accounting information. And "decision making is important [...]. Decisions move things and set processes in motion that will lead to intended, unintended and surprising effects in the future” (Mouritsen \& Kreiner, 2016, p. 22).

Then, a relevant role should be reserved to the science of "doing", nevertheless it has been long relegated to a secondary discipline compared to the science of "reporting". The reasons for such a paradox can be found in the history of the corporation and on how the rules for governing it changed over time in the western society.

This article shows the growth of management accounting as a discipline in the last century. After this short introduction, the next section describes the role of management accounting as a discipline and its relationships with accounting. Subsequently, the third section focuses on the history of management accounting as an academic discipline and the evolution in the theoretical background that shaped the science of management accounting up to nowadays. Finally, the fourth section discusses the recent evolution of management accounting in the post-modern era, and the last section briefly concludes the article.

\section{The Relationship and Roles of Accounting and Management Accounting}

Most of academic textbooks on management accounting have in their first chapter the explanation of the differences and similarities between financial accounting and management accounting. Consequentially, most of

Elisabetta Mafrolla, Assistant Professor in Accounting, Department of Economics, University of Foggia. Email: elisabetta.mafrolla@unifg.it. 
management accounting courses at universities all over the world will feasibly explain the role and the peculiarities of management accounting as a discipline with the mere comparison with the financial accounting discipline. Management accounting has long suffered the dominance of financial accounting (Richardson, 2002).

Management accounting was born together with the early 19th century's textile industries in England and the US, but unfortunately, it did not follow path by path the growing complex system of the corporation over decades. History of the industry shaped the history of accounting, but not the history of management accounting as a professional and academic discipline. According to Johnson and Kaplan (1987), most of the practices that were in use in management accounting in the late 80s dated back to the 20s, because since the firms were enforced into financial accounting practices for external usage they focused on them and started generating information that were relevant on that purpose. Management accounting practices were relegated to a secondary discipline, suffering the "dominance" of financial accounting (Richardson, 2002). As an example, management accounting courses were taught at university by financial accounting researchers (Hopper \& Bui, 2016, p. 13). Management accounting divisions used the data gathered for financial accounting purposes and elaborated them using simple and ancestor procedures, which were not sufficiently accurate for decision-making purposes and for evaluating the profitability of different productions. As narrated by Prof. Trevor Hopper (Hopper \& Bui, 2016), in 1978 management accounting research were crowded of academicians dealing with "accounting and industrial relations", whereas there was a few of them (including himself) pursuing the new-born "behavioural accounting".

In the late 80s, a wave of criticism about the pertinence of management accounting brought those practices into a crisis and into a fundamental change towards more appropriate solutions (Drury, 2003, p. 21), which lead to the rise of management accounting as a discipline grounded on the behavioural theory.

This manuscript lies in the field of behavioural accounting, as the recourse to the behavioural theory is fundamental to understand the paradox of firms with a complex and well-established management accounting system falling into the risk of default.

The wave of change registered in the 80s brought about management science and organization theory in the management accounting discipline and practice, in order to make it more anticipatory, by monitoring key environmental variables, adopting feed-forward controls, and looking for long-run survival and growth, rather than on profit maximization, and by focusing on informal and not just formal information flows and controls (Hopper \& Bui, 2016). The cost function was then assumed to be less linear and predictable than previously expected, as the mainstream of riskiness in decision-making became dominant. Incorporating risk, uncertainty, and forward-looking strategic factors into the management accounting system recently became the priority in management accounting research (Verbeeten, 2006).

\section{The Theoretical Frameworks in Management Accounting}

Management accounting as an academic discipline can be theoretically grounded into two main settings: either in the theories of organization and management, or in the theories of motivations and incentives (Gowthorpe, 2010, p. 20).

The first theories of organization and management date back to the early 19th century, when Frederick Taylor proposed the "scientific management" of work, looking at the organization of work as the perfect engine of a machine, where each employee is supposed to have a simple and specific duty. His perspective was enforced by Henri Fayol's approach to the management of organizations, based on some specific principles, 
which were supposed to drive the manager in its decision-making under a strict rationality. Furthermore, this way of thinking was corroborated by Max Weber's description of the bureaucratic organization, where the administrative process is made up of due steps and follows specific pre-defined hierarchical rules.

Management accounting has been long associated with the mechanical school of organization theory, where activities are predictable, repetitive, and structured (Gowthorpe, 2010, p. 25). Nevertheless, in a changing environment, like the one of the Western economies in the 80s, predictable actions might fail to occur. This laid the ground for the recent development of management accounting as a sociological discipline. The scientific way of thinking about organizations (and their management) was suddenly complemented by theorists advocating at the relevance of social and psychological factors, which appear when people live together, as it happens for people at workplace, because "any concrete organisational system is an economy; at the same time, it is an adaptive social structure" (Selznick, 1948, pp. 25-26), and the organization is a biological system, rather than an engineering system (Perrow, 1973).

During the crisis of the 80s, competitors from overseas were offering products at unbearable low costs in the manufacturing industry. China was admitted into the World Trade Organization (namely, the General Agreement on Tariffs and Trade) in 1995. Manufacturing capacity then moved from the West to the East of the world, where wages and raw materials were cheaper. Since then, productivity in Western economies was based on service industries, which was still developing, being often state controlled and protected by monopolist entrance barriers, and not focused on profits maximization. Most of OECD countries started a privatization and deregulation process in the 90s, which changed all the rules in competition. Management accounting, which had been developed for large-scale productions, revealed its weakness and required innovative changes, adapting its features to help managerial decisions in that historical moment. Flexibility was now entering in the production. Very often, managerial decisions had to consider not only the conditions of in-house production but also the opportunity of contracting-out. Organizations were no more hierarchically driven, but flat or matrix decisional structures emerged. Management accounting thus consisted "of juggling competing interests rather than of exerting control over people and processes” (Gowthorpe, 2010, p. 27).

The theories of motivation and incentives supported the development of management accounting as a discipline, investigating the behaviour of the management during the decisional process.

The better known theory dealing with managerial behaviour is the agency theory, which discusses the relationships between two actors: a principal and an agent. In managerial disciplines, the principal is the owner of the firm, who delegates the decisional process to an agent, who is the management of the firm. Both the principal and the agent will behave in order to maximize their utility, which, in the case of the management, is generally in terms of pay or promotion, or other economic rewards. As long as utility maximization for the management can be different from utility maximization for the owner (and the firm), a series of mechanisms are enacted in order to align the preferences of the agent to the ones of the principal. These mechanisms are generally called "incentives" and are considered as "agency costs", i.e., the costs of managing a firm through an agent. The main implication of this theoretical approach for management accounting is that the decisional process is laid in such a context, where incentives for the management need to be defined in order to maximize utility for the owner and the firm.

Another relevant theoretical background was drawn by McGregor, who hypothesized two feasible human behaviours at workplace. Under the so-called Theory X, the average human being dislikes work and avoids responsibilities; control and punishment are required to achieve objectives. Hence, in order to get profits maximization, management accounting will provide a scientific organization of the workplace, with a 
tayloristic organization and a mechanic control of results. Besides, McGregor discussed the Theory Y, under which people like to use imagination and creativity, like their work and are willing to do it, feeling responsibilities and self-posing objectives. Under this view, management accounting is based on managerial incentives which are both economic and non-economic, as workers are willing to do their job and are acknowledging non-monetary incentives that made their work more pleasant (Argyris, 1952).

Finally, a relevant step in motivation theories was made by Herzberg (1968), who shared human needs between basic and fundamental needs (so-called hygiene factors) and second order needs (growth and motivator factors), which include recognition, responsibility, and advancement. The hygiene factors are addressed in order to prevent dissatisfaction, but they would not procure satisfaction. The achievement of satisfaction depends upon the growth and motivator factors. Management accounting as a discipline should separate the mechanical control activity on the achievement of first step requirements, from the deconstructed and self-motivate system of managerial incentives to the second order goals.

Conclusively, at the beginning of the second millennium, it seemed that much of the behavioural materials, characterizing the modern approach to management accounting, were dealing with the "responsibility accounting ghetto”, but a further change was entering the discipline into the post-modern era (Birnberg, 2000, p. 715).

\section{The Post-Modern Period of Management Accounting}

The post-modern period of management accounting was encouraged by the development of information technology and the view of the organization as a complex set of interdependencies and relationships (Dekker, 2016). Management accounting was finally recognized as an instrument for strategic management and management accounting textbooks started dealing with strategic issues (Birnberg, 2000). Within a dynamic and competitive environment, in a business world of fast and cheap information flows, management accounting had to solve the issue of flexibility and competitiveness of productions, and the academic discussion moved toward the issue of how to implement management accounting system in such a complex and uncertain business world.

The recent turning point in management accounting theory and practice was additionally encouraged when the financial crisis occurred in the years 2008-2009, bringing about consequences on the economic and financial system worldwide. Theorists are still facing the consequences of that critical point in the history of accounting, and are still trying to figure out what exactly changed since then. As an expected response to economic crisis, the 2008-2009 period caused the extraordinary flourishing of information flows to outsiders, partially voluntarily (but under implicit pressures) and partially mandatorily offered by the firms (Van der Stede, 2011). Demands for more disclosure mainly addressed the corporate governance mechanisms inside the firm, but these often inevitably involved the disclosure of internal management accounting practices, showing to outsiders the managerial incentives and the performance metrics of the firm, and in some cases also its business process model, as it happened with risk management increased disclosure. Hence, management accounting is nowadays at a turning point, as pressures from outside call for increased disclosure about information that "before was mainly relegated to internal decision making” (Van der Stede, 2011, p. 612). Moreover, when crisis showed up, due to a constrained finance, firms faced the issue of rethinking their decisions, sometimes including their strategic decisions, and "had to set their budgets aside at worst, or revise them at best" (Van der Stede, 2011, p. 616). The way of doing management accounting had to adapt to the changing environment, using more flexible approaches to decision-making and planning. 


\section{Conclusions: What a Role for Management Accounting Tomorrow?}

Recent renewed interest in regulation enhancing disclosure and providing information about the internal processes in the firm basically derives from the need to control uncertainty. Nevertheless, management accounting is not typically an instrument for external reporting, as it better operates in the context of "doing" than in the one of "reporting" in order to control uncertainty within the firm. The flourishing of regulation imposing risk reporting is a clear explanation of how the legislators and the practitioners are trying to unravel the knots of inefficient reporting of firms, asking them to disclose their "doing”. Nevertheless, some knots are just tied too tight, and disclosing the strategic planning of the firm might sound odd to most of managers, who will pretend and disclose simplified and flat standard-complying reports, instead of their real strategies.

\section{References}

Argyris, C. (1952). The impact of budgets on people. New York, NY: Cornell University Press.

Birnberg, J. G. (2000). The role of behavioral research in management accounting education in the 21st century. Issues in Accounting Education, 15(4), 713-728.

Dekker, H. C. (2016). On the boundaries between intrafirm and interfirm management accounting research. Management Accounting Research, 31(1), 86-99.

Drury, C. (2003). Cost and management accounting: An introduction. London: Thompson Learning.

Gowthorpe, C. (2010). Management accounting. Andover, Hampshire, UK: South-Western Cengage Learning EMEA.

Herzberg, F. (1968). One more time: How do you motivate employees? Harvard Business Review, 46(1), 53-62.

Hopper, T., \& Bui, B. (2016). Has management accounting research been critical? Management Accounting Research, 31(1), 10-30.

Johnson, H. T., \& Kaplan, R. S. (1987). Relevance lost: The rise and fall of management accounting. Harvard Business School Press.

Mouritsen, J., \& Kreiner, K. (2016). Accounting, decisions and promises. Accounting, Organizations and Society, 49(1), 21-31.

Perrow, C. (1973). The short and glorious history of organizational theory. Organizational Dynamics, 2(1), 2-15.

Richardson, A. J. (2002). Professional dominance: The relationship between financial accounting and managerial accounting, 1926-1986. The Accounting Historians Journal, 29(2), 91-121.

Selznick, P. (1948). Foundations of the theory of organization. American Sociological Review, 13(1), 25-35.

Van der Stede, W. A. (2011). Management accounting research in the wake of the crisis: Some reflections. European Accounting Review, 20(4), 605-623.

Verbeteen, F. H. M. (2006). Do organizations adopt sophisticated capital budgeting practices to deal with uncertainty in the investment decision? A research note. Management Accounting Research, 17(1), 106-120. 